за допомогою електронних та віртуальних підручників; можливе використання навчальних програм, використання пакетів для розв'язання професійних завдань; самоконтроль і контроль).

Упровадження будь-якої інновації у процесі навчання студентів, як правило, забезпечує позитивний результат, проте на сучасному етапі організації навчального варто здійснити розроблення цілісної технології, яка повинна забезпечити досягнення дидактичних цілей і як наслідок - формування творчої особистості фахівця.

\title{
Література
}

1. Васюренко О. Вищій освіті - ефективний розвиток / О. Васюренко// Вища школа. - 2001. - № 1. - С. 83-90. 2. Максимов О. Системний підхід до вивчення дисциплін вищої школи / О. Максимов // Рідна школа. - 2006. - № 1. - С. 17-19. 3. Про проведення педагогічного експерименту 3 кредитно-модульної системи організації навчального процесу. - Наказ МОН України № 48 від 23.01.2004 р. 4. Сазонов Б. А. Индивидуально-ориентированная организация учебного процесса как условие модернизации высшего образования / Б. А. Сазонов// Высшее образование в России. - 2011. - № 4. - С. 10-24. 5. Салми Д. Как государства добиваются международной конкурентоспособности университетов: уроки для России / Д. Салми, И. Д. Фрумин // Вопросы образования. - 2013 № 1. - С. 25-68. 6. Формы организации учебного процесса [Електронний pecypc] - Режим доступу: http://www.ict.edu.ru/ft/003625/2.html/ 7. Царенко О. М. Механіка: віртуальний курс лекцій [Електронний ресурс] - Режим доступу: http://wiki.kspu.kr.ua/index.php/. 8. Larionova G. Information-activities point of view as the possible basis of higher mathematics/ 2-d International conference on the teachingof mathematics (at the undergraduate level). University of Crete. 1-6 July 2002. Hersonissos. Crete. Greece.

УДК 378.026:744

Людмила Цвіркун

\section{ДИДАКТИЧНІ ПІДХОДИ ТА ПРИНЦИПИ ФОРМУВАННЯ ПРОЕКТНО- КОНСТРУКТОРСЬКОЇ КОМПЕТЕНТНОСТІ У ПРОЦЕСІ ВИВЧЕННЯ ГРАФІЧНИХ ДИСЦИПЛІН}

Цвіркун Л. О. Дидактичні підходи та принципи формування проектноконструкторської компетентності у процесі вивчення графічних дисциплін.

У статті запропоновано дидактичні підходи та принципи, які сприятимуть успішному формуванню проектно-конструкторської компетентності у процесі вивчення графічних дисциплін; зазначено, що комплексне застосування компетентнісного, системного та особистісно зорієнтованого підходів забезпечить не лише засвоєння практичного та теоретичного матеріалу, а й активізує інтелектуальний та вольовий потенціал майбутнього інженера. Автор акцентує увагу на тому, що єдність загальнодидактичних та специфічних принципів сприятиме розвитку особистості та їі подальшому професійному становленню.

Ключові слова: інженер, графічні дисципліни, дидактичні підходи, дидактичні принципи, проектно-конструкторська компетентність.

Цвиркун Л. О. Дидактические подходы и принципы формирования проектноконструкторской компетентности в процессе изучения графических дисциплин.

В статье предложены дидактические подходы и принципы, способствующие успешному формированию проектно-конструкторской компетентности в процессе 
изучения графических дисциплин; указано, что комплексное применение компетентностного, системного и личностно ориентированного подходов обеспечит не только усвоение практического и теоретического материала, но и активизирует интеллектуальный и волевой потенциал будущего инженера. Автор акцентирует внимание на том, что единство общедидактических и специфических принципов будет способствовать развитию личности и ее дальнейшему профессиональному становлению.

Ключевые слова: инженер, графические дисциплины, дидактические подходы, дидактические принципы, проектно-конструкторская компетентность.

Tsvirkun L. O. Didactic approaches and principles of design and engineering expertise in the process of studying graphic disciplines.

In the article didactic approaches and principles that contribute to the successful formation of design competence in the process of studying graphic disciplines are offered, it is indicated that the combined application of the competency, system and personalityoriented approach will ensure not only the absorption of practical and theoretical material, but also activates the intellectual and volitional potential of future engineer. The author focuses on the fact that the unity of obschedidakticheskie and specific principles will facilitate the development of personality and its further professional development.

Key words: engineer, graphic discipline, didactic approaches, didactic principles, design and engineering expertise.

На сучасному етапі реформування системи освіти висуваються нові вимоги до майбутніх інженерів, з-поміж яких уміння розв'язувати виробничо-технічні, проектно-конструкторські, комунікативно-соціальні завдання. Тому головною метою сучасної освіти $є$ така організація навчального процесу, яка забезпечить спроможність випускника відповідати запитам ринку та рівню розвитку інформаційнокомунікаційних технологій.

Серед основних завдань сучасної дидактики $\epsilon$ формування пізнавального інтересу та позитивної мотивації до навчання графічних дисциплін, що вимагає спільної діяльності викладача та студента. Це потребує застосування відповідних дидактичних підходів та принципів, удосконалення методів, прийомів та засобів навчання, які сприятимуть становленню проектно-конструкторської компетентності майбутніх інженерів. Так, О. Овчарук зазначає, що головним у навчанні повинні бути не окремі знання, уміння та навички, а здатність і готовність майбутнього фахівця до ефективної та продуктивної діяльності в різних соціально-значущих ситуаціях [3, c. 16]. Тому успішне формування ПКК залежить від багатьох чинників, які $\epsilon$ складниками цього багатофункціонального процесу.

Mema cmammi- визначити дидактичні підходи та принципи навчання, які сприятимуть успішному формуванню проектно-конструкторської компетентності майбутнього інженера у процесі графічної підготовки.

У контексті проблеми, що з'ясовується, окреслимо дидактичні підходи, комплексне застосування яких сприятиме ефективному формуванню ПКК: компетентнісний, системний, особистісно зорієнтований.

1. Компетентнісний підхід. Науковці, які досліджують проблему компетентнісного підходу в освітньому процесі (І. Агапова, З. Бакум, Н. Бібік, С. Бондар, М. Головань, Н. Голуб, Е. Зеєр, І. Зимня, В. Кальней, В. Краєвський, Л. Паращенко, О. Пометун, В. Серіков, М. Холодна, А. Хуторський, С. Шишов), зазначають, що реалізація компетентнісного підходу полягає у визначенні 
компетенцій та компетентностей, необхідних для подальшої навчальної та професійної діяльності.

Застосування компетентнісного підходу у процесі графічної підготовки $\epsilon$ важливою проблемою сучасної педагогіки, розв'язання якої спрямовано на ефективне формування проектно-конструкторської компетентності майбутніх інженерів. Про це свідчать праці дослідників: І. Столбова «Управління якістю предметної підготовки в технічному ВНЗ на основі компетентнісного підходу (на прикладі графічної підготовки студентів)»; О. Пузанкова «Формування професійних інженернографічних компетенцій студентів у процесі навчання комп'ютерної графіки»; О. Вох «Формування графічних компетенцій у майбутніх інженерів у процесі самостійної пізнавальної діяльності»; М. Іголкіна «Педагогічні умови забезпечення компетентнісного підходу у підготовці майбутніх інженерів».

Науковці у своїх роботах визначають базові графічні компетенції, які необхідно опанувати майбутньому інженеру у процесі графічної підготовки. Так, О. Пузанкова вважає, що до основних (базових) компетенцій, які формуються у процесі вивчення графічних дисциплін, необхідно віднести такі: розвиток просторового мислення; здатність до аналізу графічної інформації; знання ГОСТів та стандартів ССКД; уміння будувати зображення просторових форм на площині; навички автоматизованого виконання інженерно-графічних робіт; володіння прийомами тривимірного моделювання засобами інформаційно-комунікаційних технологій [4, с. 46]. Проте слід зауважити, що перелік окреслених компетенцій, якими має володіти майбутній інженер, може змінюватися залежно від потреб ринку праці.

Майбутній інженер у процесі вивчення графічних дисциплін повинен оволодіти знаннями, уміннями та навичками, які відповідатимуть не лише встановленим традиційним вимогам до проектно-конструкторської діяльності (виконання технічних та робочих креслень, схем тощо), а й новим запитам ринку та рівню розвитку новітніх технологій (за допомогою графічних програм виконувати креслення, розробляти проектно-конструкторську документацію тощо).

На основі зазначеного вище можна стверджувати, що компетентнісний підхід у процесі графічної підготовки посідає одне з чільних місць та забезпечує:

- набуття компетенцій, що передбачає використання дидактичних методів та технічних засобів, які сприяють засвоєнню знань, набуттю вмінь та способів їх подальшої реалізації;

- оволодіння знаннями, уміннями та навичками, які відповідатимуть не лише встановленим традиційним вимогам до проектно-конструкторської діяльності, а й новим запитам ринку та рівню розвитку IКТ.

2. Системний підхід. Науковці, які досліджують різні аспекти застосування системного підходу в процесі навчання (3. Бакум, С. Гончаренко, К. Гуревич, Є. Гусинський, Н. Кузьміна, І. Підласий, Л. Русинова, В. Серіков, А. Фурман, I. Якиманська,) зазначають, що у процесі реалізації системного підходу зміст навчання повинен відображати цілісну систему знань, що забезпечить набуття вмінь узагальнювати навчальну інформацію. Так, 3. Бакум наголошує, що системний підхід дає змогу використовувати принцип системності як мислительну технологію, що реалізує на практиці цілісний розгляд явищ [1, с. 136].

Ефективність формування ПКК майбутніх інженерів залежить від правильно дібраної сукупності теоретичного та практичного матеріалу, який дозволить сформувати цілісну систему знань у процесі навчання. А. Фурман уважає, що у процесі вивчення графічних дисциплін студенти повинні оволодіти графічними вміннями та навичками, які забезпечать формування в їх свідомості такої структури 
знань, що відповідатиме майбутній професійній діяльності [6, с. 114]. Відповідно, необхідно застосовувати спосіб «систематизації знань»: від розгляду цілісної системи (наприклад, «Креслення як графічна система», «Перетин площин як система», «Розріз - система» тощо) до аналізу їі структури, розгляду окремих елементів цієї системи та визначення зв'язків між ними.

У процесі графічної підготовки майбутні інженери повинні оволодіти графічними знаннями, які дозволять сформувати цілісну систему знань, що вимагає умінь узагальнювати та систематизувати отриману інформацію. Така організація навчального процесу сприятиме засвоєнню не лише практичного матеріалу, а й формуватиме здатність до конкретизації та порівняння.

Застосування системного підходу у процесі вивчення графічних дисциплін дає змогу майбутнім інженерам у процесі розв'язування навчально-пізнавальних задач виконувати прийоми мислительного характеру: аналіз, синтез, порівняння, узагальнення, що $є$ необхідним для розвитку просторового мислення та уяви. Так, Л. Русинова вважає, що системний підхід у процесі графічної підготовки посідає важливе місце, оскільки $є$ методологічним засобом, який регулює напрям вибору способів розв'язування навчально-пізнавальних задач, а також теоретичних i практичних способів необхідних для цього [5, с. 268]. Тому використання евристичних методів у процесі розв'язування конкретних завдань практичного та теоретичного характеру сприятиме розумінню та засвоєнню графічних знань.

Відповідно, системний підхід $є$ одним з найважливіших методологічних засобів сучасної графічної підготовки та забезпечує:

- комплексне навчання графічних дисциплін як цілісної системи, що відображає різноманіття взаємопов'язаних елементів у процесі графічної підготовки;

- здійснення аналізу окремих елементів системи, що сприяє засвоєнню не лише практичного матеріалу, а й формуватиме прийоми мислительного характеру;

- вибір способів розв'язування навчально-пізнавальних задач, теоретичних i практичних засобів, необхідних для цього, за допомогою евристичних методів.

3. Особистісно зоріснтований підхід. Науковці, які досліджують проблеми застосування особистісно зорієнтованого підходу у процесі навчання (В. Беспалько, Є. Бондаревська, С. Грачова, Є. Гусинський, Н. Ничкало, В. Сєріков, О. Савченко, Н. Тализіна, Ю. Турчанінова, І. Якиманська) зазначають, що особистісно зорієнтований підхід сприяє не лише активній пізнавальній діяльності у процесі оволодіння предметним змістом згідно з освітніми та професійними вимогами, а й зумовлює усвідомлення мети навчання.

Формування ПКК тісно пов'язано з реалізацією освітньої, практичної, виховної та розвивальної мети у процесі графічної підготовки. Тому необхідно не лише формувати професійні знання, уміння та навички, а й розвивати якості, які дозволять інженеру реалізуватися в майбутній професійній діяльності: цілеспрямованість, відповідальність, кмітливість, креативність, творчість. Це сприятиме не лише активізації внутрішніх ресурсів, а й набуттю вмінь застосовувати інтелектуальний та вольовий потенціал у процесі розв'язування різноманітних навчальних та професійних завдань.

У майбутніх інженерів у процесі вивчення графічних дисциплін $є$ достатньо потенціальних можливостей для розвитку особистості здатної до збагачення та зростання свого освітнього потенціалу. На цьому наголошує С. Грачова, акцентуючи увагу на тому, що особистісний, оригінальний підхід до розв'язування графічних задач, виникнення нових теоретичних ідей гарантує прагнення до саморозвитку особистості. Це вимагає організації навчального процесу 3 графічних дисциплін 3 
використанням принципів співпраці, поєднання теорії та практики, принципів виховання талантів (проблемності, евристичності, рефлексії), що сприятиме не лише отриманню індивідуального досвіду, а й виникненню потреб самореалізації, самовизначення та саморозвитку [2, с. 52].

Тому студенти повинні бути забезпечені відповідними засобами навчання (посібниками, методичними рекомендаціями, збірниками задач для самостійного розв'язування, довідковими таблицями), що сприятиме саморозвитку та рефлексії у процесі графічної підготовки. Усе це забезпечує стійке засвоєння програмного матеріалу 3 графічних дисциплін та формуванню особистості, яка прагне до саморозвитку та самореалізації у процесі подальшого навчання у ВНЗ.

На основі вищезазначеного можна констатувати, що особистісно зорієнтований підхід у процесі графічної підготовки майбутніх інженерів забезпечує:

- активну пізнавальну діяльність у процесі оволодіння предметним змістом графічних дисциплін згідно з освітніми та професійнимих вимогами;

- активізацію інтелектуального та вольового потенціалу у процесі розв'язування різноманітних навчальних та професійних завдань;

- оригінальний підхід до розв'язування графічних задач, виникнення нових теоретичних ідей, що гарантує прагнення до саморозвитку майбутнього інженера.

Ураховуючи основні завдання сучасної дидактики, не менш вагоме місце у процесі формування проектно-конструкторської компетентності майбутнього інженера посідають дидактичні принципи. Науковці (Ю. Бабанський, З. Бакум, В. Беспалько, В. Загвязинський, М. Скаткін, О. Савченко, Я. Коменський, В. Оконь, В. Паламарчук, І. Підласий, К. Ушинський) у своїх працях вказують на значущість дидактичних принців у процесі навчання. Так, З. Бакум акцентує увагу на загальнодидактичних принципах, що зумовлюють доцільний вибір методів і прийомів навчання, забезпечують належний рівень засвоєння навчального матеріалу. Автор зазначає, що принципи повинні виступати не ізольовано, а в органічному взаємозв'язку, доповнюючи й зумовлюючи один одного [1, с. 38].

Реалізація будь-якого дидактичного підходу передбачає вибір відповідних принципів навчання. Тому зосередимо увагу на окремих принципах, співвідносних 3 окресленими вище дидактичними підходами процесу формування ППК майбутніх інженерів у процесі вивчення графічних дисциплін.

Пропонуємо розглянути сутність деяких дидактичних принципів, які необхідно враховувати у процесі графічної підготовки майбутніх інженерів.

Загальнодидактичні: принщии науковості (вимагає відображення у змісті графічних дисциплін сучасних наукових положень 3 урахуванням перспектив розвитку науки та техніки); принцип наочності (демонстрація викладачем на дошці зразків правильного, творчого підходу до розв'язування навчально-пізнавальних задач, виконання студентами завдань за наочним зразком); приниип послідовності $i$ систематичності (потребує послідовного міжпредметного взаємозв'язку у процесі навчання загальноінженерних та спеціальних дисциплін); принцип зв'язку теорії 3 практикою (є необхідним у процесі формування ПКК, оскільки передбачає використання завдань, пов'язаних із реальними проблемами майбутньої професійної діяльності); принции самостійності й активності (полягає у створенні сприятливих умов під час навчання графічних дисциплін, у процесі яких студент прагне працювати не пасивно, а активно обмінюючись знаннями та досвідом).

Специфічні: принцип проблемності (полягає в поступовому ускладнені графічних задач та завдань, для розв'язування яких студент сам активно формує нові знання за допомогою викладача та інших студентів); принц̧ип професійної 
мобільності (є необхідним у процесі формування проектно-конструкторської компетентності, тому що майбутній інженер повинен не лише оволодіти теоретичними та практичними знаннями, а й розвивати свій інтелект, творчі здібності, що $є$ необхідним для майбутньої діяльності).

Отже, комплексне застосування компетентнісного, системного та особистісно зорієнтованого підходів забезпечить не лише ефективне засвоєння практичного та теоретичного матеріалу, а й активізує інтелектуальний та вольовий потенціал майбутнього інженера. Єдність загально дидактичних та специфічних принципів сприятиме розвитку особистості та іiі подальшому професійному становленню. Це забезпечить успішне формування ПКК майбутнього інженера у процесі вивчення графічних дисциплін.

\section{Література}

1. Методика навчання української мови в середніх освітніх закладах/ 3. П. Бакум, І. В.Гайдаєнко, О. М. Горошкіна та ін. / за заг. ред. М. І. Пентилюк. - К. : Ленвіт, 2005. - 400 с. 2. Грачева С. В. Совершенствование процесса обучения начертательной геометрии с использованием учебного пособия развивающего типа : дис. канд. пед. наук : спец. 13.00.08 / Светлана Владимировна Грачева- М., 2006. 234 с. 3. Овчарук О. В. Компетентності як ключ до оновлення змісту освіти / О. В. Овчарук // Стратегія реформування освіти в Україні. - К., 2003. - С. 13-41. 4. Пузанкова А. Б. Формирование профессиональных инженерно-графических компетенций студентов в процессе обучения компьютерной графике : дис. канд. пед. наук: спец. 13.00.08 / Александра Борисовна Пузанкова - М., 2012. - 190 с. 5. Русинова Л. П. Системный подход в изучении начертательной геометрии / Л. П. Русинова // Молодой ученый. - М., 2010 - № 9.- С. 268-273. 6. Фурман А. В. Повышение эффективности графической подготовки школьников (на материале предметов черчения и трудового обучения 4-8 классов) : дис. канд. пед. наук: спец. 13.00.01 / Анатолий Васильевич Фурман. - К., 1984. - 210 с.

\section{ЧИННИКИ ФОРМУВАННЯ КОНКУРЕНТОСПРОМОЖНОСТІ ВНЗ}

Цебро Я. І. Чинники формування конкурентоспроможності ВНЗ.

У статті висвітлено основні проблеми забезпечення конкурентоспроможності закладів освіти, 3 урахуванням сьогоденних реалій. Охарактеризовано сутність поняття «конкурентоспроможність ВНЗ» та визначено основні чинники іiі формування. Обгрунтовано значимість кожного 3 чинників у процесі підвищення конкурентоспроможності.

Ключові слова: конкуренція, конкурентоспроможність, конкурентоспроможність ВН3, фактор, показники.

Цебро Я. И. Факторы формирования конкурентоспособности вузов

В статье отражены основные проблемы обеспечения конкурентоспособности учебных заведений, учитывая настоящем реалии. Охарактеризована сущность понятия «конкурентоспособность вуза» и определены основные факторы ее формирования. Обоснована значимость каждого из них в процессе повышения конкурентоспособности.

Ключевые слова: конкуренция, конкурентоспособность, конкурентоспособность вузов, фактор, показатели. 